\title{
Notes on the occurrence of Sitticus terebratus (CLERCK, 1758) in Poland
}

\author{
Robert ROZWALKA* and Jadwiga STACHOWICZ** \\ *Department of Zoology, University of Maria Curie-Sklodowska, Akademicka 19, 20-033 Lublin, Poland; \\ e-mail: arachnologia@wp.pl \\ **Department of Chemistry, University of Life Sciences in Lublin, Akademicka 15, 20-950, Lublin, Poland
}

\begin{abstract}
Sitticus terebratus is a spider species known from a few localities in Poland. The records refer to the south Poland - in the West Beskid and the Orawa-Nowy Targ Basin, as well as in the north-eastern part of the country. The study revealed 13 new localities of this species ranging from the Babia Gora Mts to Bieszczady Mts. All sites of $S$. terebratus are synanthropic but observations indicate that the species is very rare and it may be endangered both in Poland and in Europe.
\end{abstract}

Key words: Sitticus terebratus, Poland, distribution, rare spide, Babia Góra Mts, Bieszczady Mts

\section{INTRODUCTION}

The range of Sitticus terebratus (Clerck, 1758) covers most of the northern and continental Europe, however this species is not found on the Iberian Peninsula and the Balkan Peninsula (Fuhn \& Gherasim 1995, Nentwig et al. 2014, Metzner 2014, Van Helsdingen 2014, Staudt 2014). Besides, it is noted from the Caucasus (Logunov \& Guseinov 2001) and from the southern, western and central part of Siberia (Danilov \& Logunov 1993, Rakov 1998, Logunov \& Marusik 2000).

It is rather a rare spider in the rest of Europe and known from not many locations (Harm 1973, Fuhn \& Gherasim 1995, Gajdoš \& Svatoň 1993, Gajdoš et al. 1999, Buchar \& Rỉžička 2002, Nentwig et al. 2014, Metzner 2014, Staudt 2014). In Poland, Sitticus terebratus is considered as a rare species, collected mainly in the southern and north-eastern part of the country (Prószyński \& Staręga 1971, Staręga 1976, 1996, 2003a, 2003b, Kupryjanowcz 2005) (Table 1). According the literature data, the typical habitat of $S$. terebratus are sunny rock walls, tree trunks, walls of buildings, fences, etc. (Prószyński \& Staręga 1971, Żabka 1997, Almquist 2006, Nentwig et al. 2014).

The new data extend the view on the distribution of Sitticus terebratus in Poland.

\section{RESULTS}

The following 13 new localities of Sitticus terebratus were found in the Babia Góra Mts, Tatra Mts, the Eastern Beskids, and the Bieszczady Mts (Fig. 1):

Babia Góra National Park: Hala Śmietanowa [CV 99], wooden walls of an old forester house (ca. $828 \mathrm{~m}$ a.s.1.), 17 Aug 2014, $1 \delta$; leg. R. Rozwalka.

Bieszczady National Park: Tarnawa Niżna [FV 34], wooden walls of a tourist house (ca. 690 m a.s.1.), 2 May 2013, 1 juv.; leg. R. Rozwałka.

Bystre near Ustrzyki Dolne [FV 26], a sunlit wooden walls of an old orthodox catholic church (ca. 600 m a.s.1.), 20 Aug 2012, 1 juv.; leg. R. Rozwalka.

Czarne near Wyszowatka [EV 28], wooden walls of an old shed (ca. $480 \mathrm{~m}$ a.s.1.), 13 Jun 2013, 1ठ; leg. R. Rozwalka. 


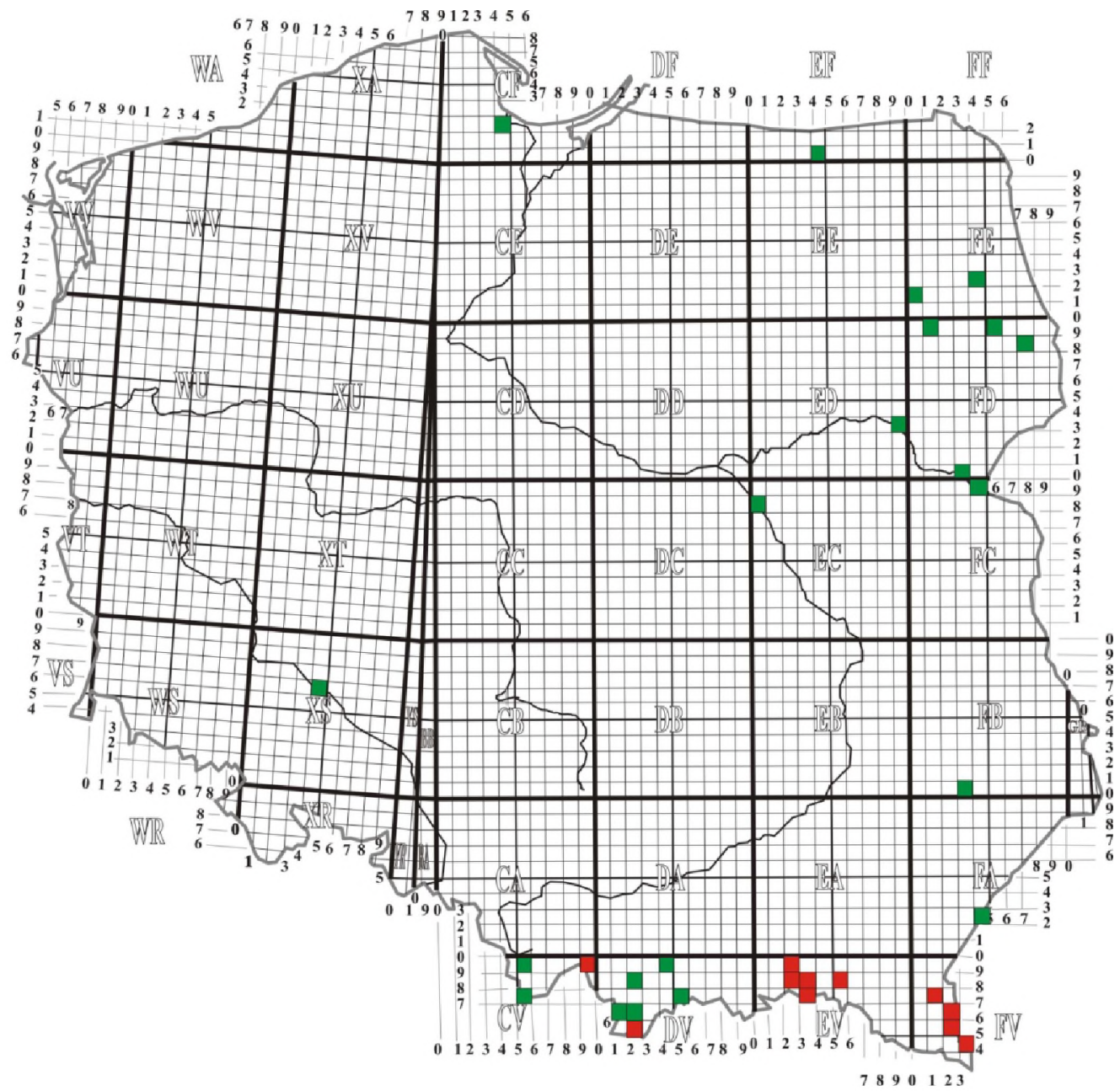

Figure. 1. Distribution of Sitticus terebratus in Poland: green square - quoted literature data (details in Appendix):, red square - new data.

Jasień near Ustrzyki Dolne [FV 17], on a sunlit trunk of a larch (ca. $455 \mathrm{~m}$ a.s.1.), 20 Aug 2012, 18; leg. R. Rozwalka.

Kotań near Krempna [EV 38] (Fig. 2), heavily sunlit wooden walls of an old orthodox catholic church (ca. $400 \mathrm{~m}$ a.s.1.), 30 May 2013, $1{ }^{\AA}$; and a few specimens observed on $16 \mathrm{Aug}$ 2013; leg. et obs. R. Rozwalka \& J. Stachowicz.

Krempna [EV 38], sunlit wooden fence (ca. 370 m a.s.1.), 2 Jun 2013, 1 ; leg. R. Rozwalka.

Królik Polski [EV 58], sunlit wooden walls of an old catholic church (ca. $445 \mathrm{~m}$ a.s.l.), 16 Aug 2013, 1우 1 1juv.; leg. J. Stachowicz.

Magura National Park: Grab near Ożenna [EV 37], wooden walls of an old forester house (ca. 475 m a.s.1.), 17 Aug 2013, 1 ${ }^{\wedge}$; leg. R. Rozwalka. 
Rozdziele [EV 29], sunlit wooden walls of an old catholic church (ca. $340 \mathrm{~m}$ a.s.1.), 16 Aug 2013, $2 \precsim \hat{\jmath}$; leg. J. Stachowicz.

Równia near Ustrzyki Dolne [FV 17], sunlit wooden walls of an old belfry (ca $505 \mathrm{~m}$ a.s.1.), 9 Jun 2012, 18 ; leg. R. Rozwalka.

Smolnik near Ustrzyki Dolne [FV 25], sunny wooden walls of an old orthodox catholic church (ca. $580 \mathrm{~m}$ a.s.1.), 20 Aug 2012, 1, $2 \hat{\delta}$; and a few specimens observed during the courtship; leg. et obs. J. Stachowicz \& R. Rozwalka.

Tatra National Park: Polana Kopieniec (Clearing Kopieniec) [DV 25], sunlit wooden walls of an old shepherd's hut (ca. 1240-1250 m a.s.1.), 2 Aug 2013, 19, $2 \hat{\jmath} \hat{\delta}$; and a few specimens was observed in the same place; leg. et obs. R. Rozwalka.

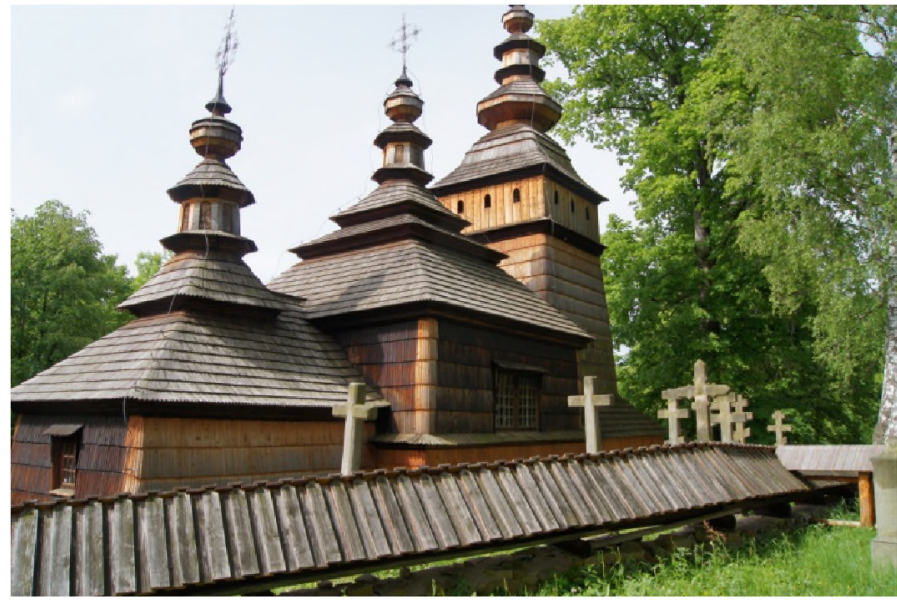

Fig. 2. Habitat of Sitticus terebratus in Kotań near Krempna, 30 May 2013. Photo by R. Rozwałka.

The materials are deposited by Robert Rozwalka in Department of Zoology UMCS in Lublin.

The search carried out in central and eastern Poland (Lublin Upland, Roztocze) gave negative results.

\section{DISCUSSION}

During the current study, we failed to confirm the presence of S. terebratus in Zakopane and Kościelisko, where Kulczyński $(1881,1884)$ found this species, but some specimens of this species was found in the Tatra Mts. The new location in the Tatra National Park shows that the upper limit of Sitticus terebratus occurrence in Poland is not $930-950 \mathrm{~m}$ a.s.l. as it has been noted by Kulczyński $(1881,1884)$, but reaches about $1250 \mathrm{~m}$ a.s.l. In addition to the negative searching results in Podhale, Sitticus terebratus was not found in many putative localities in the Beskid Mts and the Bieszczady Mts, where many suitable habitats for it were searched. This indicates that this spider species occurs in Poland in a few scattered localities whichare distributed almost exclusively in the north-eastern and southern parts of the country (Appendix 1). In the rest of Poland, it is presumably absent, because there is no evidence in literature (Table 1).

Possible cause of the discontinuity in S. terebratus occurrence is the competition with S. pubescens. Both species live in the same environment - on sunlit walls of the buildings and sunlit tree trunks (Żabka 1997). However, S. pubescens is much less demanding species - it is also found on the brick walls, rock walls, in quarries, etc. (Żabka 1997, Almquist 2006). 
Because of the greater ecological tolerance, S. pubescens is much more common (Fig. 3), but it occurs rather to the height of about $600 \mathrm{~m}$. a.s.l. (Prószyński \& Staręga 1971). Kulczyński (1881) already pointed out that these species competed with each other and that $S$. pubescens was more common in the lowlands and replaced by $S$. terebratus in the mountains.

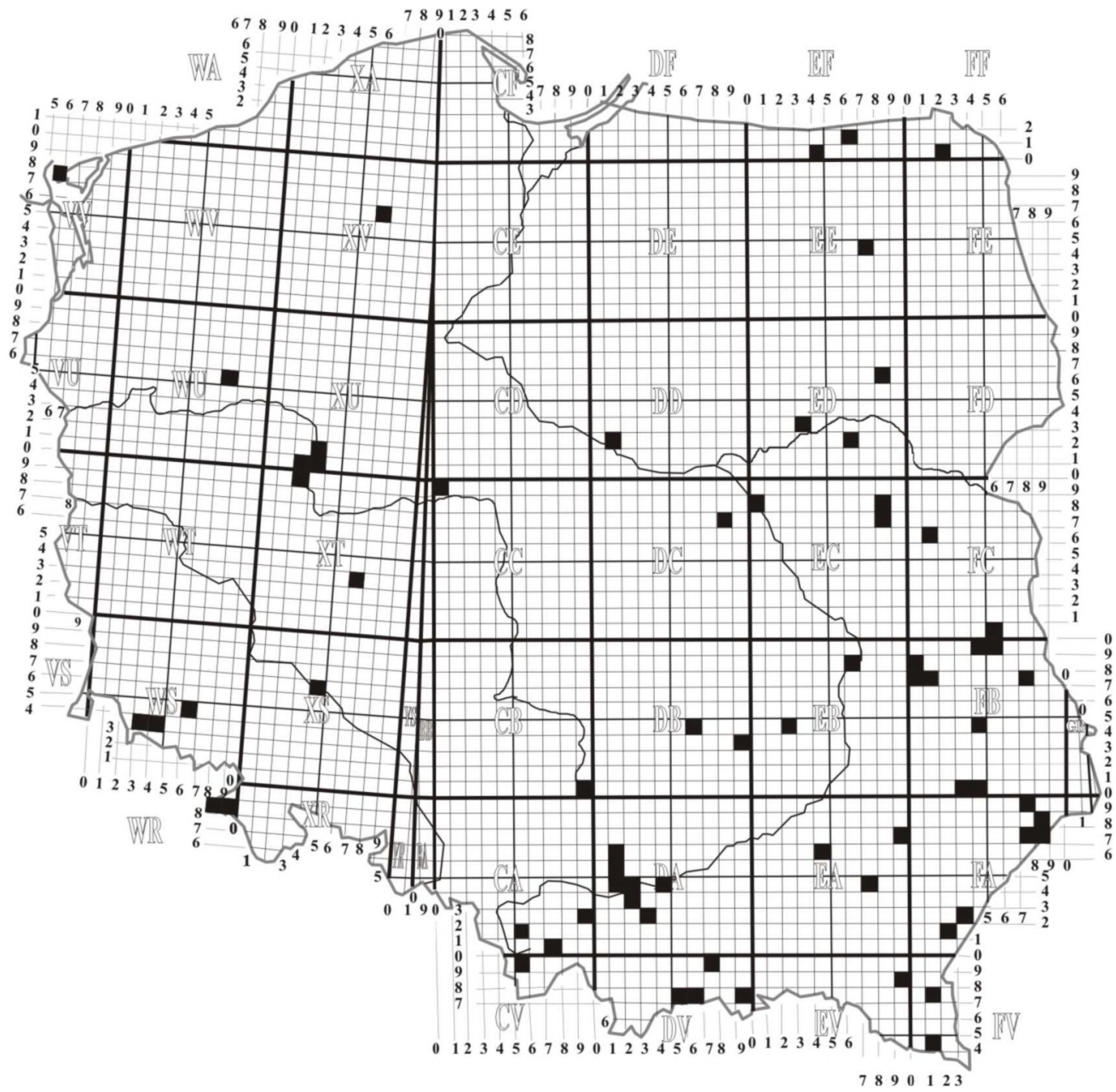

Figure. 2. Distribution of Sitticus pubescens in Poland according unpublished data of W. Starega (pers. comm.: DD 12 - Plock, ED 86 - Dlugobórz, EC 87 - Siedlce, FF 20 - Jeleniewo, WS 64 - Miłek Mts. Reserve), R. Rozwałka \& J. Stachowicz (FA 88 - Jarczów) and R. Rozwalka (EA 46 - Hucina, EA 97 - Kolacznia, FA 32 - Bolestraszyce FB 40 Zwierzyniec, FB 59 Urszulin, FC 50 Pieszowola).

Majority of S. terebratus specimens were found on the walls of the old wooden churches (Fig. 2) and sometimes also on the tree trunks, but always in the vicinity of buildings. None of the recent findings come from the natural habitats, such as sunlit tree trunks on the edges of forests, rock walls, rocky slopes that are listed in the literature as typical for this species (e.g., Miller 1971, Prószyński \& Staręga 1971, Zabka 1997, Buchar \& Rúžička 2002). The lack of natural stands in Poland what was observed in our research and in the majority of bibliographic data (Appendix 1), indicates that $S$. terebratus occurs in Poland mainly in synanthropic environments. 
Analyzing the bibliographic data, it can be seen, that $S$. terebratus was probably much common species than it is today. Kulczyński $(1881,1884)$ placed in his publications detailed remarks on the distribution and on the number of collected specimens of rare species. In the case of $S$. terebratus he gave only the number of stands from the southern Poland, with no comment on its frequency. It what suggests that at that time the species was easy to find. The research conducted by authors in 2009-2014 in the Beskid Mts, Tatra Mts, and Bieszczady Mts led to the discovery of 13 new locations of S. terebratus. However, the results indicate also that this spider is very rare. The fact that $S$. terebratus was not found in Zakopane and adjacent areas suggests that the spider might have become very rare, or it is even extinct there. The absence of $S$. terebratus in the places of its past findings is probably related to the two factors.

First, the disappearance of wooden buildings, what took place especially in the second half of the twentieth century. Thus, $S$. terebratus lost most of its preferred habitats. Second is likely associated with the expansion of Leiobunum limbatum L. Koch. This invasive harvestmen species is widespread in Poland along the whole foothill band now (Rozwatka \& Starega 2012, R. Rozwałka unpubl. data). It was observed that $L$. limbatum displaces native opiliones species e.g., Opilio parietinus (De Geer), Mitopus morio (Fabricius), which until recently were common on the walls of buildings or in the city parks (Rozwalka \& Starega 2012, R. Rozwałka unpubl. data). L. limbatum often formes "mono-species opiliocenoses", in which there is no place for other opiliones species. The impact of $L$. limbatum on spiders inhabiting the walls of buildings is unknown, but for instance, it was observed that the harvestmen was eating Steatoda bipunctata (Linnaeus) (R. Rozwatka unpubl. data). Such an observation suggests that $S$. terebratus may also be a victim of $L$. limbatum.

\section{ACKNOWLEDGEMENTS}

The authors thank Prof. W. Staręga for complementing the information about unpublished locations of S. pubescens.

\section{REFERENCES}

Almeust S. 2006. Swedish Araneae. Part 2. The families Dictynidae to Salticidae. Entomologica scandinavica, Supplement 63, $320 \mathrm{pp}$.

BUCHAR J. \& RŮŽIČKA V. 2002. Catalogue of spiders of the Czech Republic. Peres, Praha, 351 pp.

DANILOV S.N. \& LOGUNOV D.V. 1993. Faunistic review of the jumping spiders of Transbaikalia (Aranei Salticidae). Arthropoda Selecta 2: 25-39.

DZIABASZEWSKI A. 1990. Fauna Roztocza: zasoby, przemiany, ochrona. Materialy z sympozjum, Zwierzyniec, 25-27 września 1990. Instytut Zoologii PAN, Warszawa, 53 pp.

FUHN I.E. \& GHERASIM V.F. 1995. Fauna României: Arachnida. Vol. 5. Familia Salticidae. Academiei Române, Bucuresti, $301 \mathrm{pp}$.

GAJdOŠ P., SVATOŇ J. \& SLOBODA K. 1999. Catalogue of Slovakian spiders. Bratislava, 337 pp.

GAJdoš P. \& SVATOŇ J. 1993. The red list of spiders of Slovakia. Bollettino dell'Accademia Gioenia di Scienze Naturali 26: 115-133.

HARM M. 1973. Zur Spinnenfauna Deutschlands, XIV. Revision der Gattung Sitticus Simon (Arachnida: Araneae: Salticidae). Senckenbergiana biologica 54: 369-403.

HELSDNGGEN P.J. VAN. 2014. Fauna Europaea: Arachnida: Araneae. Fauna Europaea version 2.6.2. Available at http:/www.faunaeur.org.

KOZŁOWSKI M. \& ŻABKA M. 2006. Nuptial feeding in Sitticus terebratus (Clerck, 1757) (Araneae: Salticidae)? Newsletter of the British Arachnological Society 105: 6-7.

KRZYŻANOWSKA E., DZIABASZEWSKI A., JACKOWSKA B. \& STARĘGA W. 1981. Spiders (Arachnoidea, Aranei) of Warsaw and Mazovia. Memorabilia Zoologica 34: 87-110.

KULCZYŃSKI W. 1881. Wykaz pająków z Tatr, Babiej Góry i Karpat szlązkich z uwzględnieniem pionowego rozsiedlenia pająków żyjących w Galicji zachodniej. Sprawozdania Komisyi Fizyograficznej 15: 1-75.

KULCZYŃSKI W. 1884. Przegląd krytyczny pająków z rodziny Attoidae żyjących w Galicyi. Rozprawy i Sprawozdania Wydziału Matematyczno-Przyrodniczego Akademii Umiejętności 12: 136-232. 
Kupryjanowicz J. 2005. Pająki (Araneae) Biebrzańskiego Parku Narodowego. In: DYRCZ A. \& WERPACHOWSKI C. (eds), Przyroda Biebrzańskiego Parku Narodowego, pp. 275-299. Biebrzański Park Narodowy, OsowiecTwierdza, 440 pp.

LOGUNOV D.V. \& GUSEINOV E.F. 2001. Faunistic review of the jumping spiders of Azerbaijan (Aranei: Salticidae), with additional faunistic records from neighboring Caucasian countries. Arthropoda Selecta 10: 243-260.

LOGUNOV D.V. \& MARUSIK Y.M. 2000. Catalogue of the jumping spiders of northern Asia (Arachnida, Araneae, Salticidae). KMK Scientific Press Ltd, Moscow, 299 pp.

MENGE A. 1876. Preussische Spinnen. IX. Fortsetzung. Schriften der Naturforschende Gesellschaft in Danzig (N. F.), 4: 455-494.

METzNER H. 2014. Worldwide database of jumping spiders (Arachnida, Araneae, Salticidae). Available at http:/www.jumping-spiders.com/ (Dec 2014).

MLleR F. 1971. Ŕád Pavouci - Araneida. In: DANIEL M. \& ČERNÝ V. (eds), Klíč zvíŕeny ČSSR IV. Praha, 51-306.

NENTWIG W., BLICK T., GLOOR D., HÄNGGI A. \& KROPF C. 2014. Spiders of Europe. Available at www.araneae.unibe.ch (Dec 2014).

Prószý́ski J. \& STARĘGA W. 1971. Pająki - Aranei. Katalog Fauny Polski, Warszawa, 33: 382 pp.

RAKOV S.Y. 1998. On the fauna of jumping spiders of the southern part of West Siberia (Aranei: Salticidae). Arthropoda Selecta 7: 305-311.

ROZWALKA R. \& STAREgGA W. 2012. Distribution of Leiobunum limbatum L. KOCH, 1861 (Opiliones: Sclerosomatidae) in Poland. Fragmenta Faunistica 55: 177-183.

StaręGa W. 1976. Pajaki (Aranei) Pienin. In: Riedel A. \& StaręGa W. (eds), Fauna Pienin. I. Warszawa, 370 pp. Fragmenta Faunistica 21: 233-330.

STAREGGA W. 1978. Materiały do znajomości rozmieszczenia pająków (Aranei) w Polsce, III-VII. Fragmenta Faunistica 23: $259-302$.

StaręGa W. 1995. Pająki Puszczy Knyszyńskiej. In: Czerwníski A. (ed.), Puszcza Knyszyńska. Monografia przyrodnicza, pp. 279-298. Zespól Parków Krajobrazowych, Supraśl, 510 pp.

STARĘGA W. 1996. Spinnen (Araneae) aus der Borkenheide und anderen Lokalitäten der Masurischen Seenplatte. Fragmenta Faunistica 39: 287-311.

STARĘGA W. 2000: Spinnen aus Roztocze und anliegenden Gebieten. Fragmenta Faunistica 43: 59-89.

STARĘGA W. 2003a. Pająki (Araneae) Puszczy Knyszyńskiej. Nowy Pamiętnik fizjograficzny 1: 95-206.

STARĘGA W. 2003b. Pająki z Nadbużańskiego Parku Krajobrazowego. Parki Narodowe i Rezerwaty Przyrody 22: 531-541.

StarĘGA W. \& Kupryjanowicz J. 1996. Beitrag zur Kenntnis der Spinnen (Araneae) des Gorce-Gebirges. Fragmenta Faunistica 39: 313-328.

STAUDT A. 2014. Nachweiskarten der Spinnentiere Deutschlands. (Arachnida: Araneae, Opiliones, Pseudoscorpiones). Available at http:/www.spiderling.de/arages/ (Dec 2014).

TACZANOWSKI W. 1866. Spis pająków zebranych w okolicach Warszawy w ciągu roku 1865. Wykaz Szkoły Głównej Warszawskiej, Warszawa, 5: 1-14.

ŻABKA M. 1997. Salticidae - Pająki skaczące (Arachnida: Araneae). Fauna Polski, 19, Warszawa, 189 pp.

\section{STRESZCZENIE}

\section{[Uwagi o występowaniu Sitticus terebratus (ClerCK, 1758) w Polsce]}

Sitticus terebratus jest w Polsce pajakiem rzadkim, znanym z nielicznych stanowisk zlokalizowanych glównie w Beskidzie Zachodnim i Kotlinie Orawsko-Nowotarskiej, oraz w pólnocno-wschodniej Polsce. Przeprowadzone badania przyniosly informacje o 13 nowych stanowiskach, rozproszonych od Babiej Góry po Bieszczady, ale zebrane obserwacje wskazuja, że jest to pajak bardzo rzadki i nieliczny. Wszystkie stanowiska S. terebratus mialy charakter synantropijny, nie udalo się odszukać tego gatunku w biotopach naturalnych. Autorzy przypuszczaja, że $S$. terebratus na terenie Polski - a możliwe, że i w Europie - jest gatunkiem ginącym. Sugerują też, że przyczyną zanikania $S$. terebratus jest ubywanie preferowanych środowisk, jakimi są silnie nasłonecznione ściany drewnianych zabudowań, a ponadto konkurencja i drapieżnictwo ze strony inwazyjnego kosarza - Leiobunum limbatum. 
Appendix. Literature data on occurrence of Sitticus terebratus in Poland ${ }^{1}$

\begin{tabular}{|c|c|c|c|}
\hline Author & Site & $\begin{array}{l}\text { UTM } \\
\text { GRID }\end{array}$ & Notes \\
\hline Taczanowski 1866 & Warszawa & $\mathrm{EC} 08$ & $\begin{array}{l}\text { occurrence unconfirmed following the } \\
\text { publication by Krzyżanowska et al. } \\
\text { (1981) and W. Staręga (pers. comm.) }\end{array}$ \\
\hline Menge 1876 & Gdańsk-Stogi & $\mathrm{CF} 42$ & \\
\hline \multirow{4}{*}{ Kulczyński 1881} & Racza Hala & CV 57 & \\
\hline & Barania Góra & CV 59 & \\
\hline & Gronik & DV 15 & \\
\hline & Zakopane & DV 26 & \\
\hline \multirow{7}{*}{ Kulczyński 1884} & Barania Góra & CV 59 & \\
\hline & Racza Hala & CV 57 & \\
\hline & Kościelisko & DV 15 & $\begin{array}{l}\text { this record probably refers to Gronik that } \\
\text { was mentioned in the previous work by } \\
\text { Kulczynski }(1881)\end{array}$ \\
\hline & Zakopane & DV 26 & \\
\hline & Klikuszowa & DV 28 & \\
\hline & Starzawa & FA 42 & \\
\hline & Ustrzyki Dolne & FV 17 & \\
\hline \multirow{4}{*}{ Prószyński \& Staręa 1971} & Serpelice & FC 49 & W. Staręga (unpubl. data) \\
\hline & Mierzwice & FD 30 & W. Staręga (unpubl. data) \\
\hline & Zwierzyniec & FB 30 & W. Starega (unpubl. data) \\
\hline & Wroclaw & XS 46 & S. Pilawski (unpubl. data) \\
\hline Staręga 1976 & Krościenko & DV 57 & \\
\hline Staręga 1978 & Mierzwice & FD 30 & \\
\hline Dziabaszewski 1990 & generally, Roztocze" & FB $30 ?$ & $\begin{array}{l}\text { according to Starega ( } 2000) \text {, these are } \\
\text { inaccurate data, that refer to Zwierzyniec }\end{array}$ \\
\hline Staręga 1995 & Supraśl & FD 59 & \\
\hline Staręga 1996 & Węgorzewo & $\mathrm{EF} 40$ & \\
\hline $\begin{array}{l}\text { Staręga \& Kupryjanowicz } \\
1996\end{array}$ & Magurki & DV 49 & \\
\hline \multirow{3}{*}{ Staręga 2003a } & Supraś1 & FD 59 & \\
\hline & Wierobie & FD 88 & \\
\hline & Janów & FE 42 & \\
\hline Staręga 2003b & Kiełpiniec & ED 93 & \\
\hline Kupryjanowicz 2005 & Gugny & FE 01 & \\
\hline Kozłowski \& Żabka 2006 & Tykocin & FB 19 & \\
\hline
\end{tabular}

\footnotetext{
${ }^{1}$ Without such publications as check-lists, catalogs, etc. that do not contain the original data
} 